\title{
The blinkered discipline?: Martti Koskenniemi and interdisciplinary approaches to international law
}

\author{
DAVID ROTH-ISIGKEIT \\ Research fellow, Normative Orders, Cluster of Excellence, Goethe University, Frankfurt/Main, Germany
}

E-mail: david.roth-isigkeit@normativeorders.net

\begin{abstract}
This article is concerned with the debate about interdisciplinary methods in international law, in particular the turn to International Relations. It finds the historical critique of Martti Koskenniemi grounded in a more methodological issue: the turn toward a redefinition of norm properties impedes on the critical discursive quality of law. Shaping this historical critique into a research question that allows for meaningful engagement, the article discusses Koskenniemi's charges drawing on recent constructivist scholarship. Giving an account of what it means to be 'obliged' to obey the law, this article defends the coherence of Koskenniemi's position and suggests that we should take the critique of the interdisciplinary project between law and International Relations seriously. While it agrees that a significant part of the discourse fails to appreciate the particularities of the law, it suggests that understanding legal obligations requires taking the institutional autonomy of the law into account. Respecting this autonomy, in turn, points to a multi- instead of an interdisciplinary project. The reflexive formalist conception of the law that this article advocates captures the obligating nature of the law, independent of the normative content of particular rules.
\end{abstract}

Keywords: interdisciplinarity; international relations theory; functionalism; analytic jurisprudence; constructivism; legal theory

The turn toward interdisciplinarity is one of the most significant developments in the theory of international law and relations. ${ }^{1}$ While the body of

\footnotetext{
1 The landmarks of the debate are inter alia Ratner and Slaughter, 'Appraising the Methods of International Law - A Prospectus for Readers', 93 American Journal of International Law (1999) 291; Goldstein et al., 'Introduction: Legalization and World Politics', 54(3) International Organization (2000) 385; M. Byers (ed.), The Role of Law in International Politics: Essays in International Relations and International Law (2000); J. C. Barker, International Law and International Relations (2000); In 2004, the Journal of International Law and International Relations is introduced; Further publications are C. Reus-Smit (ed.), The Politics of International Law (2004); E. Benvenisti and M. Hirsch (eds), The Impact of International Law on
} 
research under the label IL/IR is firmly established, particularly in the United States, ${ }^{2}$ the agenda has stimulated critique from leading international legal theorists for its anti-formalist concept of legal obligation, most prominently Martti Koskenniemi. His critique was perceived by many as a broadside attack on American approaches toward international law and a generalized rejection of the discipline of International Relations. The debate, in which Koskenniemi accused his opponents of being vassals of American hegemony, has escalated quickly. Jeffrey Dunoff and Mark Pollack, editors of the 2013 volume Interdisciplinary Perspectives on International Law and International Relations: The State of the Art, suggested there was 'Madness in Martti's method'. ${ }^{3}$ Pollack adds: 'This is not only an historical argument about the past, but one that speaks to, and condemns in not just intellectual but also moral terms, one of the central developments in contemporary American International Law'. ${ }^{4}$ It is probably not exaggerated to say, that among International Relations scholars and among many international lawyers there is a relatively wide agreement that this time Koskenniemi locked the wrong target.

This article argues that taking up this belief misses a great chance - that is to understand (and defend) in detail what legal theorists explain as the source of legal obligation. For many observers of international legal method, Martti Koskenniemi is a puzzling theorist. This is due to the fact that his scholarship unites two seemingly countervailing, almost paradoxical positions. On the one hand, Koskenniemi is one of the principal figures of the critical legal studies movement, highlighting the necessity to

International Cooperation (2004); H. H. Koh and O. A. Hathaway, Foundations of International Law and Politics (2004); B. H. Simmons and R. H. Steinberg, International Law and International Relations (2007); T. Biersteker et al. (eds), International Law and International Relations: Bridging Theory and Practice (2007); D. Armstrong et al., International Law and International Relations (2007); J. L. Dunoff and M. A. Pollack (eds), Interdisciplinary Perspectives on International Law and International Relations: The State of the Art (2012). For a good overview of different publications, see R. J. Beck, 'International Law and International Relations Scholarship', in D. Armstrong et al. (eds), Routledge Handbook on International Law (2009), 13.

${ }^{2}$ Irish et al., 'Bridging the International Law-International Relations Divide: Taking Stock of Progress', 41 Georgia Journal of International and Comparative Law (2013) 357, have monitored the practice. Interestingly, they find a peak of common scholarship around the year 2000, with negative tendency. See also Schaffer and Ginsburg, 'The Empirical Turn in International Legal Scholarship', 106 American Journal of International Law (2012) 1.

${ }^{3}$ Dunoff, 'From Interdisciplinarity to Counterdisciplinarity: Is There Madness in Martti's Method?', 27 Temple International \& Comparative Law Journal (2013) 309.

${ }^{4}$ Pollack, 'Is International Relations Corrosive of International Law? A Reply to Martti Koskenniemi', 27 Temple International \& Comparative Law Journal (2013) 339, at 348. 
understand the indeterminacy of formal legal rules in order to adequately grasp the bias in supposedly value-neutral processes of legality. On the other hand, he defends a formalist method with respect to legal obligations. This is surprising, since for many critical legal theorists, formal law constitutes hegemonic power and, as such, is already part of the problem. While the first aspect of his thought seemingly makes a case for opposing formal law, the second suggests formalism. One of the reasons why scholars tend to reject Koskenniemi's criticism are thus issues of coherence: in short, how can Koskenniemi criticize anti-formalism in the turn toward interdisciplinarity while holding up an anti-formalist view in his critical studies?

Giving an account of what it means to be 'obliged' to obey the law, this article defends the coherence of Koskenniemi's position and suggests that we should take the critique of the interdisciplinary project between law and International Relations seriously. The argument begins with a conscientious mapping of Koskenniemi's contentious discussion of the genesis of the discipline of International Relations in his seminal history of international law, the Gentle Civilizer of Nations. This narration prepares the ground for the rejection of interdisciplinary approaches that he aligns with Schmittian anti-formalism. Shaping this historical critique into a research question that allows for meaningful engagement, the article discusses Koskenniemi's charges drawing on recent constructivist scholarship. While it agrees that a significant part of the discourse fails to appreciate the particularities of the law, it suggests that understanding legal obligations requires taking the institutional autonomy of the law into account. Respecting this autonomy, in turn, points to a multi- instead of an interdisciplinary project. The reflexive formalist conception of the law that this article advocates captures the obligating nature of the law, independent of the normative content of particular rules.

\section{Martti Koskenniemi and the History of International Relations}

The ultimate pages of Koskenniemi's Gentle Civilizer of Nations artfully connect and contrast Hans Morgenthau's lifeline with the one of Carl Schmitt, the Kronjurist of the Nazi regime and deliver at the same time a pointed critique of IL/IR approaches. Since International Relations as a discipline was historically the counter-project to international law, interdisciplinary cooperation would not only be fruitless but dangerous. Koskenniemi argues that both scholars, Schmitt and Morgenthau, agreed that international law represented a liberal strategy of depolitization. 'International law would channel political tensions into committees, assemblies, and formal dispute settlement mechanisms. All of this was illusion. Depolitization was a politics by the status quo powers to 
consolidate their advantages'. ${ }^{5}$ The idea that depolitization could constitute a threat was the result of the experience with the Weimar constitution in Germany in the inter-war years. 'The Constitution of Weimar stood only because it was enacted; it was the formalist's dream of a pure law come true, with an ironic twist, valid without support from society or from a general sense of justness'. ${ }^{6}$ From Weimar's failure that Schmitt had not only predicted but also appreciated, he derived the conclusion that sovereignty was not a legal concept but rather essentially tied to effectiveness, the control of the police. A law that is supposed to matter would need to be oriented on the factual order, not in utopian dreams of formal validity. Law is either marginalized or subordinated to the political; this is according to Koskenniemi the central message of International Relations.

Morgenthau traced the failure of the League of Nations back to this problem constellation. He would have preferred a federal order with a direct line to the world police but since this was politically not in reach, he opted for marginalization. ${ }^{7}$ Whereas he defended the ideal of the rule of law in the domestic realm, law had no place in an essentially political environment of the international arena. Consequently, Morgenthau gave up any study of international law. ${ }^{8}$ With the tension between the ideal of a world federation and the conviction of the irrelevance of law without police, Morgenthau opened the academic window for a new discipline, International Relations, that was founded on its distinctiveness from the formal adherence to legal rules that had dominated the study of the international realm in the United States before. ${ }^{9}$ The crisis of international law in the war era had provoked its counter-project.

Carl Schmitt, in contrast, opted for a redefinition of international law in functional terms, a conception of the new nomos as part of a new international law, a revolution of the legal form. ${ }^{10}$ Law should be dynamic and

${ }^{5}$ M. Koskenniemi, The Gentle Civilizer of Nations: The Rise and Fall of International Law, 1870-1960 (2002), at 461.

${ }^{6}$ M. Koskenniemi, 'Carl Schmitt, Hans Morgenthau, and the Image of Law in International Relations', in M. Byers (ed.), The Role of Law in International Politics: Essays in International Relations and International Law (2000) 17, at 17.

7 See, for example, Morgenthau, 'Positivism, Functionalism and International Law', 34 American Journal of International Law (1940) 260.

${ }^{8}$ With respect to Morgenthau's scholarship, see C. Frei, Hans J. Morgenthau: An Intellectual Biography (2001).

${ }^{9}$ Koskenniemi, supra note 5, at 465-66.

${ }^{10}$ Even though both, Morgenthau and Schmitt, had been thinking about a redefinition, only Schmitt delivered one. Koskenniemi, 'Law, Teleology and International Relations: An Essay in Counterdisciplinarity', 26 International Relations (2012) 3, at 10. 
deformalized, always ready to respond to politically changing realities. This responsiveness was put into practice by American legal realism. Myres McDougal and Harold Lasswell, the founders of the New Haven School, understood the role of international lawyers as 'anti-communist policy advisers'. ${ }^{11}$ The attention was turned away from exegetic work to recommending strategic choices. Their rule-skepticism was underlined with a call for interdisciplinarity since the then-empty legal method required input from closely connected disciplines. This international law understood as 'language of a powerful and a confident actor with an enviable amount of resources to back up its policies', ${ }^{12}$ was essentially an enforcement plan for the American world order design.

Whereas Schmitt opened the notion of law for policy, Morgenthau became Koskenniemi's hero at the event of the invasion of the Dominican Republic in 1965. Here, Morgenthau recognized the consequences of the call for a deformalized approach: 'American Globalism of necessity culminates in a pax Americana or American imperium in which the political interests and legal values are identified with universal ones'. ${ }^{13}$ Unlike his American legal colleagues, Morgenthau refrained from judgment about the legality of the intervention. He accepted the irrelevance of international law but was not willing to give American foreign policy the legitimizing stamp of legality. ${ }^{14}$

\section{Counterdisciplinarity! The Schmittian Origin of the IL/IR Project}

Koskenniemi makes his argument against interdisciplinarity drawing on the different reactions of Morgenthau and Schmitt to the impotence of rules: interdisciplinary approaches are rooted in Carl Schmitt's call for the relevance of international law through adaptation to the concrete order.

11 Koskenniemi, supra note 5, at 474.

12 Ibid., at 480 .

13 Ibid., at 482, cites H. J. Morgenthau, 'Emergent Problems of United States Foreign Policy', in L. Gross et al. (eds), The Relevance of International Law: Essays in Honor of Leo Gross (1968) 47 , at 55-56.

14 A similar discussion that contains interesting insights in the debate culture of the time, opposing formalist approaches to McDougal's policy-oriented jurisprudence, can be found in Falk, 'The Adequacy of Contemporary Theories of International Law', 50 Virginia Law Review (1964) 231. Falk discusses the different legal views on the emplacement of Soviet missiles in Cuba (at 234-35). For Falk, all three approaches of formalism (Kelsen), cynicism (Morgenthau) and policy-oriented jurisprudence (McDougal) remain unsatisfying (at 233). Rather, he argues: 'For with law, as with the social sciences, progress at this stage of development requires that traditions of undisciplined speculation be gradually supplanted by increasingly rigorous methods of analysis and observation' (at 265). His view thus seems to point to a rather functional and ethically agnostic approach. I am grateful to an anonymous reviewer for pointing me to Falk's article. 
'The concern for relevance of international law arose as the shared obsession of the profession, "relevance" being defined as instrumental usefulness whose measurement seemed to call for complex sociological and policy oriented analyses'. ${ }^{15}$ This very idea of relevance corrupts the legal form and ' $[\ldots]$ the interdisciplinary agenda itself, together with a deformalized concept of law, and enthusiasm about the spread of "liberalism," constitutes an academic project that cannot but buttress the justification of American empire, as both Schmitt and McDougal well understood'. ${ }^{16}$ In Koskenniemi's narrative, appealing to relevance ends up promoting the same mechanisms that allowed the Nazi to take power in Germany after the failure of Weimar: political power bends legal form.

In IL/IR scholarship, Koskenniemi rediscovers these anti-formalist roots. The interest of interdisciplinary studies lies in questions how and for what purpose international law is used and how states can reach their goals with its instruments. These questions are a recurring theme: Morgenthau's and Schmitt's call for the relevance of international law. 'For instrumentalism, law is a functional technique and legal problems are technical problems'. ${ }^{17}$ In this view, law is about what works. It shifts the distinction between law and non-law to criteria of functionality - something would be law as long as it fulfills the goals of the policy-maker. ${ }^{18}$ This, in turn, would mean a loss of its counterfactual dimension: functionally defined law would be merely apologetic, that is, affirmative to the powerful.

To cure this apologetic structure of interdisciplinary scholarship, the theoretical project turned to normativism. 'Today, interdisciplinary scholars in American academia hope to control the dangers of instrumentalization by accompanying it by a normative optic received from "democracy" and "liberalism". ${ }^{19}$ In this world of deformalized laws the definition of the universal is set free. Normativity, however, is highly influenced by undisclosed power structures. Paradigmatically, Anne-Marie Slaughter combines a sociological account on how the world has become a fluid and dynamic place where (government) networks are the decisive actors with a claim on a normative requirement for an individualized universalism. ${ }^{20}$ Interdisciplinary projects of this kind are aiming at a

${ }^{15}$ Koskenniemi, supra note 5, at 483.

${ }^{16}$ Ibid., at 484 .

17 Ibid., at 485 .

18 Ibid., at 487.

19 Ibid., at 488 .

${ }^{20}$ A.-M. Slaughter, A New World Order (2004). Morgenthau suggested an individualized rule of law, a similar paradox. 
replacement of formal sovereignty by more convincing assumptions about how the world really works. ${ }^{21}$ The argument for the IL/IR project is therefore inevitably connected with its underlying assumptions: 'it cannot be divided from the kinds of sociology and ethics that are being advocated'. ${ }^{22}$

In a later article, Koskenniemi describes particular steps in which Slaughter's Dual Agenda had overtaken the discourse in shaping a vocabulary beyond sovereignty. Regime theory shifted the focus from formal institutions to 'rules, norms and decision-making procedures around which actor's expectations emerge'. ${ }^{23}$ Robert Keohane's agenda was to prevent international treaties from being treated as law if they had no behavioral impact. ${ }^{24}$ Within regimes there had to exist several different policy choices that required to abandon the binary code of law in favor of hard and soft law: (hard) rules became (softer) regulation. Kenneth Abbott had already been calling in 1989 for an interdisciplinary turn, urging international lawyers to give up their rule-formalism and instead learn to generate hypotheses. ${ }^{25}$ In 2000, Abbott and Duncan Snidal published Hard Law and Soft Law in International Governance, an article that became one of the landmark references of interdisciplinary scholarship. ${ }^{26}$ The move from government to governance indicated a shift from formal to informal management of conflicts. Now, even for violations of international law the vocabulary was redefined in terms of observations of non-compliance within reporting mechanisms.

In the formalist's narrative, these steps point to an important conceptual shift. They reduced the original legal vocabulary as far as possible and replaced it with an obscure sense of the good: legitimacy. But, as Koskenniemi argues, 'legitimacy is not about substance. Its point is to avoid such substance but nonetheless to uphold a semblance of substance [...] to

${ }^{21}$ A good example for such scholarship is D. A. Lake, Hierarchy in International Relations (2009).

${ }^{22}$ Koskenniemi, supra note 5, at 488-89.

23 S. D. Krasner, International Regimes (1983). See a discussion in Koskenniemi, 'Miserable Comforters: International Relations as New Natural Law', 15 European Journal of International Relations (2009) 395, at 408.

${ }^{24}$ R. Keohane, 'The Analysis of International Regimes: Towards a European American Research Programme', in V. Rittberger and P. Mayer (eds), Regime Theory and International Relations (1993) 23, at 26.

25 Abbott, 'Modern International Relations Theory: A Prospectus', 14 Yale Journal of International Law (1989) 335.

${ }^{26}$ Abbott and Snidal, 'Hard Law and Soft Law in International Governance', 54 International Organization (2000) 421. 
ensure a warm feeling in the audience'. ${ }^{27}$ Legitimacy vocabulary provided the normative cover for rational egoism in which non-compliance is merely a 'cost'. This move prepared the final appropriation of the discourse, the shift in authority to speak as experts because the legal craft, interpreting rules, had become superfluous. 'In Morgenthau as well as in today's liberal deformalized jurisprudence interdisciplinarity comes with two sides: an argument about sociology and an argument about ethics. The sociological argument makes law indistinguishable from the preferences of the persons whom fate and power have put in decision-making positions. The ethical argument seeks to avoid the critique that this makes law simply a collection of the prejudices of the decision-makers, seeking to replace the constraint rules failed to offer'. ${ }^{28}$

Koskenniemi's alternative is to call for a culture of formalism, a call for international lawyers to uphold the distinctiveness of their craft and not to empty the notion of validity with opening it to the disposition of the policy-maker. Formalism, in opposition to normativism, means a positivist concept of law combined with narrow rules of legal interpretation. IL/IR approaches lead to 'the transformation of the formal into a façade for the material in a way that denies the value of the formal as such'. ${ }^{29}$ The universalism of international law stands in contrast to the universalism of American International Relations scholarship. Whereas the latter is a positive morality based on preferences of the powerful, the former is a negative, in 'resistance to subsumtion under particularist causes' ${ }^{30}$

\section{From Historical Critique to Theoretical Engagement}

Koskenniemi's artful narrative woven in a historical critique complicates its engagement today. Arguably, it seems questionable whether the historical argument is correct - Morgenthau can hardly be depicted as the single intellectual founding father of International Relations and Schmitt's influence on American international theory is equally unclear. Yet, rejecting Koskenniemi's argument merely as a result of this historical imprecision would be premature.

27 Koskenniemi, supra note 23, at 409.

28 Koskenniemi, supra note 5 , at 489.

29 Ibid., at 501.

30 Ibid., at 504. Similar Jan Klabbers: 'What lawyers should do, of course, instead of bowing to the demands of a coy and flirtatious realism, is play hard to get. Lawyers, academic lawyers at least, should refuse to give up the "simplifying vigor" that characterizes law, and should be ready to defend its values and its modesty, its purity, if you will, with a wink and a nod to Kelsen'. Klabbers, 'The Relative Autonomy of International Law or The Forgotten Politics of Interdisciplinarity', 1 Journal of International Law \& International Relations (2005) 35, at 41-42. 
The narrative contains an important argument against today's progressive developments in IL/IR scholarship. The two central terms that Koskenniemi uses in his reconstruction of the genesis of International Relations as a discipline are marginalization and instrumentalism. While the former is reserved for Morgenthau's central argument of the lack of power to enforce international legal norms, he connects the calls for interdisciplinarity with instrumentalism. Instrumentalism in this context means complicity to American hegemony in world politics.

One of the reasons why Koskenniemi's central point has been underestimated is his failure to account for the complexity of today's International Relations scholarship. Given the development of large critical strands within the discipline, rejecting the interdisciplinary project on these grounds seems inappropriate. While the early IL/IR approaches had been dominated by liberal agendas, like Slaughter's government networks, these have even been discarded from within the discipline as instrumentalist. Criticizing the framework of Legalization and World Politics, a milestone for the IL/IR movement, ${ }^{31}$ Finnemore and Toope argued from a constructivist perspective that it failed to account for the obligatory character of law. ${ }^{32}$ This critique of the interdisciplinary agenda from inside International Relations seemed to point to the same mistakes as Koskenniemi did and aimed at delivering more adequate conceptions of interdisciplinary scholarship.

Today's progressive advocates of the IL/IR project equally tend to share Koskenniemi's critique of the New Haven School and related social science approaches to international law that describe law as a process of decisionmaking. Lasswell and McDougal, to whom Koskenniemi explicitly refers, reformulated legal method as a continuous process of authoritative policydecisions oriented toward the implementation of values. ${ }^{33}$ While Brunnée and Toope argue that these approaches were 'frankly instrumentalist', they contend that similar conclusions apply to contemporary attempts to understand the nature of law. '[A]ll realists believe law will inevitably be trumped by power and interest calculations. Neo-liberal institutionalists [...] tend to treat international law instrumentally as a signalling device or a product of effective interest projection through explicit negotiation and formal adjudication. [...L]iberal theories are open to norms, but tend to project a homogeneous normativity that undermines the value diversity of

\footnotetext{
31 See Goldstein et al., supra note 1.

32 Finnemore and Toope, 'Alternatives to Legalization: Richer View of Law and Politics' 55 International Organization (2001) 743, at 744 and 748.

33 For a summary, see Reisman, 'The New Haven School: A Brief Introduction', 32 Yale Journal of International Law (2007) 575, at 576.
} 
international society. ${ }^{34}$ There is basic agreement among today's progressive advocates of interdisciplinarity and Koskenniemi on the inadequacy of the early rationalist scholarship and the social science methodology of American legal realism.

The disagreement only occurs with respect to constructivist approaches to interdisciplinarity. Here, Brunnée and Toope insist that 'constructivism is different'. ${ }^{35}$ Koskenniemi, however, observes a development in which 'constructivism also separated itself from its postmodern home and geared itself towards instrumental effect and managerial control. [...] Where International Relations constructivism believes in homogeneous ideas and undistorted communication, International Law highlights the polemical aspects of the "constructed" world - indeed it thrives on the constant putting into question of such constructions as "state," "minority," "reputation" and so on'. ${ }^{36}$ Koskenniemi thus primarily criticizes newer tendencies of constructivism that he discards as instrumentalist.

While today's proponents of interdisciplinarity tend to criticize the beginnings of constructivist work on international law, notably Onuf and Kratochwil, for their allegedly excessive reliance on positivist methodology, ${ }^{37}$ Koskenniemi seems to embrace this early work while rejecting newer approaches. ${ }^{38}$ What today's scholars arguing for interdisciplinarity consider a decisive advantage of their work - a more differentiated view on the normativity of the legal form than blunt legal positivism - leads Koskenniemi to defend a culture of formalism. In order to progress in the debate on interdisciplinarity, it is therefore necessary to inquire into this disagreement on constructivist approaches to international law. In this inquiry, it will be relevant to understand in how far the methodology of early constructivist work differs from newer approaches that are labeled as interdisciplinary.

Quite generally, Brunnée and Toope rightly insist, constructivists have a more differentiated attitude toward legality than approaches explaining state's behavior with the strictly rational pursuit of self-interest. Rather, constructivists are hesitant to use the vocabulary of causation, which intuitively resonates with the idea that law does not lead to clear

34 J. Brunnée and S. Toope, Constructivism and International Law (2012), in Dunoff and Pollack, supra note 1,119, at 120.

35 Ibid.

${ }^{36}$ Koskenniemi, supra note 10 , at 16.

37 Brunnée and Toope, supra note 34, at 125.

${ }^{38}$ Koskenniemi seems to appreciate the 'post-modern home' of constructivist scholarship. The work of Onuf and Kratochwil being intricately connected to the philosophy of language falls in this category. See Koskenniemi, supra note 10, at 16. 
input-output predictions. Constructivism as a social theory argues that there is a certain relationship between interest and identity formation. With that, constructivists are able to take into account softer factors like culture, discourse, and social norms - instead of merely making cost-benefit analyses. In taking these identity-shaping factors into account, early constructivists have drawn on the post-modern and pragmatist ideas of Foucault, Derrida, and Rorty. In the formation of interest, constructivists argue, social norms play an important role. ${ }^{39}$ Legal norms are part of this large body of social norms through which identities and behavior are shaped and reshaped in a continuous process. In principle, the qualification of a norm as law does not change the way in which it interacts with actors in this process of identity formation. This makes constructivist method relatively open toward the incorporation of different concepts of law: law is what actors make of it. ${ }^{40}$

The article aims to show in the next two sections that this relative openness of constructivist methods toward concepts of law has resulted in a variety of approaches to international law. The differences among these varieties ultimately explain Koskenniemi's rejection of current constructivist takes on international law. Early constructivists, notably Fritz Kratochwil and Nick Onuf, were overall hesitant with claims on legal method. While both revolutionized the understanding of international relations in many ways, they have stayed within the safe paths of positivist legal thought. Today, this initial hesitation is criticized by contemporary scholars. It has been replaced by a "critical" endeavor to think about law beyond the constraints of analytic positivism.

\section{Early Constructivism and the Framework of Analytic Positivism}

Constructivism as an approach to international law had existed long before calls for a joint discipline intended to revolutionize the field. ${ }^{41}$ Law played a role in constructing identities of polities, in building social norms and

${ }^{39}$ In the reference works, however, it is mostly individuals whose identities are transformed within the (alienated) context of their normative environments. This critical dimension sometimes seems to get lost in early constructivism in IR.

${ }^{40}$ Wiener and Puetter, 'The Quality of Norms is What Actors Make of It: Critical Constructivist Research on Norms', 5 Journal of International Law and International Relations (2009) 1.

${ }^{41}$ See Onuf, 'Do Rules Say What They Do? From Ordinary Language to International Law', 26 Harvard International Law Journal (1985) 385. N. Onuf, World of our Making: Rules and Rule in Social Theory and International Relations (1989). F. Kratochwil, Rules, Norms, and Decisions: On the Conditions of Practical and Legal Reasoning in International Relations and Domestic Affairs (1991). 
influence behavior through interaction. For Fritz Kratochwil, law consists in a particular process of reasoning. ${ }^{42}$ Nick Onuf suggested an image of law as ordering system built on speech act theory. ${ }^{43}$ Even though their approaches reformed the understanding of international relations as a field of mutual interaction, both have been drawing on traditional understandings of legal obligation, in particular the scholarship of H. L. A. Hart.

Nick Onuf tackles the phenomenon of law with an analysis of language. According to him, language and the construction of the world are mutually constitutive. He writes about the mutual construction: 'When we speak of order, we chose a fiction to believe in. "Order" is a metaphor, a figure of speech, a disguise. It is constituted by performative speech and constitutes propositional content for this speech'. ${ }^{44}$ By frequent repetition, a speech act, used in a specific manner, can be instituted as a rule. The way the rule interacts with the world again depends on the context in which it is used. His concept of 'rules' as general prescriptive statements relies heavily on the jurisprudence of H. L. A. Hart. ${ }^{45}$ While Hart was generally sceptical about the existence of international law as a legal system in the proper sense, ${ }^{46}$ Onuf is more optimistic that the developing United Nations system could satisfy more sophisticated criteria of formalization, external validation, and enforcement procedures. ${ }^{47}$ Onuf's account of international law resembles Hart's insofar as he does not aim to redefine the criteria Hart suggested for legality. Rather, he takes these for granted, and argues that the world has changed considerably since Hart's first assessment. ${ }^{48}$

Similarly, Kratochwil examines the role of rules in shaping decisions, drawing on critical discussions of Wittgenstein, Habermas, and Hart. ${ }^{49}$ Kratochwil suggests that rules guide action and solve problems of sociality, that is, linking the individual to a social world in which the necessity of

42 Kratochwil, supra note 41, at 205.

43 Onuf, supra note 41 , at 311.

44 Onuf, supra note 41 , at 155.

45 See, for example, N. Onuf, 'The constitution of international society', in N. Onuf (ed.), International Legal Theory: Essays and Engagements 1966-2006 (2008), 295, at 313.

46 See H. L. A. Hart, The Concept of Law (3rd ed., 2012), at 213-14.

${ }^{47}$ For a critical perspective on this approach, see B. Fassbender, UN Security Council Reform and the Right to Veto: A Constitutional Perspective (1998), at 60-61.

48 This resonates with the view that international law has evolved into a legal system even in the light of Hart's criteria. See Payandeh, 'The Concept of International Law in the Jurisprudence of H.L.A. Hart', 21 European Journal of International Law (2010) 967.

${ }^{49}$ A recent restatement and discussion of these claims can be found in F. Kratochwil, The Status of Law in World Society: Meditations on the Role and Rule of Law (2014). 
coordination arises out of the scarcity of resources. ${ }^{50}$ Rules simplify this social interaction, but more importantly, they constitute our social world. ${ }^{51}$ In exploring the relationship to decisions through deliberation and interpretation, Kratochwil focuses on the generation of law-internal normativity. In his Rules, Norms and Decisions, Kratochwil starts with discussing the 'systemic concept of law' as defended by Kelsen and Hart. ${ }^{52}$ His main point of criticism is that it does not reflect the way rules really shape decisions. Rules only establish an indicator but never a conclusive proof for a decision. ${ }^{53}$ Rather, law belongs to the realm of practical discourse that is dependent on the use of analogies and contextual adaptations that makes it largely independent from predefined rules of interpretation. The practical application of law is as much a matter of context and rhetorical figures as it is a matter of rules.

Overall, both Kratochwil and Onuf were careful to redefine the criteria of legality suggested by analytic positivism. Interdisciplinary cooperation was understood here as drawing on each other's insights without necessarily trying to subvert or redefine the other discipline's grown understandings of the own subject. Abbott and Slaughter, in their respective calls for cooperation, apparently did not perceive their work as interdisciplinary at all. Much of their work on the internal and contextual dynamics of law even resembles Koskenniemi's famous argument in From Apology to Utopia. According to him, rules are radically indeterminate. This radical indeterminacy goes much further than ambiguities of the grammar and the language of legal rules, it is not merely a semantic indeterminacy. Decisions in the law are not predetermined by the application of legal rules, Koskenniemi argues. ${ }^{54}$ With the same rules you can justify one or another policy. 'It follows that it is possible to defend any course of action including deviation from a clear rule - by professionally impeccable legal arguments that look from rules to their underlying reasons, make choices between several rules as well as rules and exceptions, and interpret rules in the context of evaluative standards'. ${ }^{55}$ For Koskenniemi, as well as for Kratochwil and Onuf, the law consists in a dynamic and contextual use of language that is continuously reshaped through legal practice.

${ }^{50}$ Kratochwil, supra note 41 , at 70.

${ }^{51}$ Ibid., at 11.

52 See, for example, Kratochwil's discussion of Hart and Kelsen, ibid., at 187-93.

53 Ibid., at 192.

${ }_{54}$ M. Koskenniemi, From Apology to Utopia: The Structure of International Legal Argument (2nd ed., 2006), at 595 .

55 Ibid., at 591 . 
Their models are easy to reconcile with the sociological interpretation of Hart's concept of law that roots the law in practical acceptance by legal subjects. Hart argued that the validity of legal rules is derived from other legal rules in a hierarchical structure. This hierarchical structure ends with an ultimate rule, the rule of recognition. Hart writes that 'the rule of recognition exists only as a complex, but normally concordant practice of the courts, officials and private persons in identifying the law by reference to certain criteria. Its existence is a matter of fact ${ }^{56}$ The rule of recognition identifies criteria determining what counts as valid law in a legal system. Insofar, as there are criteria according to which international law is identified in practice, the Hartian will identify international law as a legal system.

Seemingly, this isolated description of the rule of recognition does not explain how law can be obligatory. How can someone (or a state) subject to law regard it as legal obligation, that is to treat the law as reason-giving for one's own actions? Through the rule of recognition, we learn about criteria of legality that determine the content of the law. But none of these criteria explain in themselves why we should follow the social practice of law in the first place. One of the major critiques of early constructivist approaches mounted by today's interdisciplinary scholars is that the picture lacks precisely that: a convincing explanation of how law comes to be obligatory. ${ }^{57}$

\section{Interdisciplinarity and the Turn to Norm Properties}

Analytic legal positivism, the claim that the legality of a norm can be determined without taking into account its substantive merits, is one of the main theoretical obstacles in a meaningful dialogue with law, today's constructivists like Brunnée and Toope claim. Their argument is based on two premises. The first premise, already introduced in the last section, is that legal positivists fail to explain how law comes to be obligatory, since a social practice in itself does not provide reasons for action. The second premise is the inadequacy of the option policy-oriented jurisprudence has pursued since this would blur the distinction between legal norms and policies. As a result, both models fail to develop a sense of legal obligation. Brunnée and Toope's way out of this dilemma is to understand legal obligation in interactional terms. This section offers a discussion of their suggestion, while arguing that their attempt to capture the distinctiveness of

\footnotetext{
${ }^{56}$ Hart, supra note 46 , at 110.

57 See, for example, Brunnée and Toope, supra note 34, at 125. That this criticism does not hold true is elaborated upon in section 10 .
} 
legal obligation runs into the same conceptual problems as the policyoriented jurisprudence. ${ }^{58}$

Brunnée and Toope have argued that the unduly narrow focus on positivist method by constructivists has obstructed the dialogue. They argue that for legal positivists, 'legal norms can only exist when they are produced through fixed hierarchies, usually state hierarchies', ${ }^{59}$ 'a unidirectional imposition of authority' ${ }^{60}$ For them, Onuf, Kratochwil, and subsequent attempts from International Relations do not explain the interactional genesis of legal obligations. ${ }^{61}$ At the same time, they reject McDougal's policy-oriented jurisprudence as instrumentalist because the legal process serves to implement a contentious model of 'human dignity'. ${ }^{62}$ The interdisciplinary research program, they insist, should turn toward norm properties to better explain than legal theorists what constitutes the obligatory force of law. ${ }^{63}$

Their proposal draws on the legal theory of Lon Fuller. Fuller argued that legality involves adherence to certain minimal-normative criteria such as generality, clarity, constancy, and others. ${ }^{64}$ Brunnée and Toope suggest that when norm creation conforms to Fuller's demands, a practice of legality arises. ${ }^{65}$ These practices, ultimately, generate a law-internal legitimacy and create a sense of obligation. ${ }^{66}$ Legality, in their view, stems from normative instead from formal criteria and the normativity of legal obligation is created through a process of reciprocal interactions. These reciprocal interactions cannot be explained without taking norm properties into account.

It is important to note that their proposal resembles in many respects the early approaches of the process schools. Most significantly, it makes the same assumptions about legal formality. Both aim to define the validity of a legal norm drawing on normative criteria that are, in principle, external to

${ }^{58}$ See also, for a critical reading, Reus-Smit, 'Obligation Through Practice', 3 International Theory (2011) 339.

59 Brunnée and Toope, supra note 34, at 119.

${ }^{60}$ Ibid., at 127.

${ }^{61}$ Ibid., at 127.

${ }^{62}$ Ibid., 130-31.

${ }^{63}$ In a narrow sense, the interdisciplinary project with International Relations begins here. Whereas Onuf, Kratochwil, and other constructivists had merely drawn on insights of legal theory, Brunnée and Toope try to implement a renovated understanding of legal method.

${ }^{64}$ L. Fuller, The Morality of Law (1964), at 39.

65 J. Brunnée and S. Toope, Legitimacy and Legality in International Law: An Interactional Account (2010), at 20-55.

${ }^{66}$ For a concise summary of this argument, see ibid., at 96-97. 
the legal system. While Fuller's criteria seem more reasonable and specific than a general reference to the concept of 'human dignity' as we find it in the early process schools, the technical definition of legality does not stem from the legal system itself, but from another, external source of normativity.

This is not necessarily a problem of Fuller's theory but rather a consequence of its application to the validity of international law. Fuller's account, in principle, could be combined with positivist methodology. One would think that there is something inherently wrong in calling a normative ordering system 'legal', when it fails to conform to Fuller's criteria. However, as Liam Murphy has noted, this law-inherent morality is better understood as an implication of Fuller's work, rather than its initial motivation. ${ }^{67}$ As a description of the difference between law and other social norms, criteria of reciprocity do not seem helpful. Any kind of cooperative practice operating with respect to Fuller's criteria could live up to what legality demands. ${ }^{68}$

Brunnée and Toope thus only seemingly agree with Koskenniemi in his rejection of the process schools. While both are (rightly) skeptical about the implementation of human dignity as a criterion to determine legality, Fuller's criteria replace instrumentalist normativity with presumably more neutral terms. Kratochwil had argued that in 'McDougal's exceedingly "complex" theory about law [...] the shift of focus away from rules to the decision process often makes a distinction between "law" and "politics" virtually impossible'. ${ }^{69}$ Koskenniemi, in line with the early constructivist approaches, pointed to the technical difference of legal from political discourse, while Brunnée and Toope - missing the importance of the technical difference between legal and social norms - merely capture the questionable normativity of a broadly understood concept of 'human dignity'.

\section{Outcome-Oriented Conceptions of Legal Obligation}

This section aims to move the relatively specific discussion of Brunnée and Toope's constructivist approach back to a more general level. At its foundation, constructivism is concerned with reasons for action. When constructivist approaches turn to law, the central question is how legal obligations give rise to reasons for action: Why do states obey seemingly powerless rules? In thinking about this question, however, many International Relations scholars have run into fundamental misunderstandings of

\footnotetext{
${ }^{67}$ L. Murphy, What Makes Law? (2014), at 158 (with further references).

${ }^{68} \mathrm{Ibid}$., at 168 .

${ }^{69}$ Kratochwil, supra note 41, at 196.
} 
the answers a legal perspective has to offer. Interdisciplinary approaches to international law are blinkered (as the title of this article suggests), insofar they fall for a common but mistaken idea of what makes law obligatory and how a social practice might generate reasons for action.

The prevalent understanding within the discipline seems to be that legal normativity must reside in a form of actor's interest in an outcome. The only aspect that seems to differ across the approaches are views on what constitutes this interest. According to some, it is a form of 'enchanting' attitude toward legalization, others take an instrumentalist perspective grounded either in sociological or in ethical considerations. All three perspectives, however, fail to capture the essential feature of legality.

In its first variant, the conviction is that a legal perspective would advocate more law as a self-sufficient goal that is worth striving for. It can be exemplified in Ian Hurd's distinction between 'enchanted and disenchanted' attitudes toward legalization. ${ }^{70}$ According to Hurd, enchantment describes an intellectual position that 'begins from the premise that law represents an improvement over the political or legal relations that it replaces. It distinguishes law from politics by presuming that the turn to law adds rationality, procedure, fairness or accountability to a pre-legal antecedent condition' ${ }^{71}$ Put simply, this position views actors as having reason to engage in a practice of legality, because a legal state of affairs is normatively more desirable than a state without it.

Advocating a disenchanted view, Hurd lumps together a large part of current international law scholarship under the label of enchantment, suggesting that lawyers would fail to see the ambiguities in legalization. One central aspect for him is the claim that in the enchanted picture, legality is 'elevated to a reason for action in itself'. ${ }^{72}$ While it is doubtful that anyone would seriously defend such a position, its characterization also misconceives of a central difference. If there is a legal obligation, this obligation provides a reason for action that is independent from the content of the obligation. ${ }^{73}$ But nothing in this view implies the bold claim that more law is automatically and always better. In contrast, at the beginning of positivist theory with Jeremy Bentham stands the intention to be able to have a distant attitude toward legality in order to subject the law to moral critique. ${ }^{74}$

70 See Hurd, 'Enchanted and Disenchanted International Law', 7 Global Policy (2016) 96.

${ }^{71}$ Ibid., at 96.

${ }^{72}$ Ibid., at 98 .

${ }^{73}$ Hurd relies on (and misconceives of) the argument by S. Besson, 'The Legitimate Authority of International Human Rights', in A. Føllesdal et al. (eds), The Legitimacy of International Human Rights Regimes: Legal, Political and Philosophical Perspectives (2014) 32. See ibid., at 97.

${ }^{74}$ See, for example, L. Murphy, 'The Political Question of the Concept of Law', in J. Coleman (ed.), Hart's Postscript: Essays on the Postscript of 'The Concept of Law' (2001), 372, at 387-88. 
Taking the legal point of view, unlike Hurd seems to assume, does not mean to neglect the ambiguities of the law. Thus, naïve enchantment as a virtually indefensible philosophical position can hardly explain practices of international legality.

The second variant suggests what could be called a sociological instrumentalism. It explains the binding nature of law in the light of the functions that it fulfills for global order. These functions might be coordinative, such as allowing for communication or cooperation, and they might be constitutive for the identity of actors. Across the different approaches of liberalism and constructivism, these functions are mentioned as responses to the question why states obey international law. ${ }^{75}$ This account, however, is not complete. Taking up the distinction made by Hurd, sociological instrumentalists would see reasons for enchantment in a specific issue area. These in turn might induce reasons for legalization - in the rationalist picture because with law everyone is better off, in the constructivist picture because law constitutes the social world - but they do not explain what makes law binding and how a legal obligation might give rise to a contentindependent reason for action.

A third variant, ultimately, appeals to a form of normative instrumentalism. In this view, law is binding because and only insofar as it furthers some specific normative concerns of world society as a whole. Actors, according to this perspective, have reasons for action to follow the law because it contains normatively good commands. Normative instrumentalism differs from enchantment, because it acknowledges that legality might lead to ambiguous results. Brunnée and Toope's conception of legal obligation falls in this category, but also international law scholars engaging in the interdisciplinary project typically hold such a view. ${ }^{76}$ In American constitutional law, such a perspective has been forcefully defended by Ronald Dworkin. Dworkin himself, however, had doubts as to whether his concept were transferrable to the global realm. ${ }^{77}$ According to the normative instrumentalist perspective, the law does not provide for content-independent obligations. Rather, a legal obligation is only binding insofar it contributes to a realization of underlying normative goals, such as peace or human rights.

All three perspectives are focused on a functional explanation for practices of legality. For all of them, there seems to be a missing link between the

75 See, for an excellent summary, Armstrong et al., supra note 1, at 106-7.

76 The policy-oriented approach of the New Haven School is probably the most prominent example. A more recent approach, for example, is S. Ratner, The Thin Justice of International Law (2015).

77 See Dworkin, 'A New Philosophy for International Law', 41 Philosophy \& Public Affairs (2013) 2. 
practice of law and the categorical ought of content-independent obligations. The explanations given illustrate reasons that motivate actors to engage in practices of legality, but they do not explain what makes law binding independent of these reasons. However, a legal obligation can only be said to be present when it conveys an ought independent of whether actors consider the indicated behavior as the best option for them. Once instituted, the obligation is independent from the preferences of actors. This is the central precondition for the institutional autonomy of the law.

Within constructivism, there are approaches that have appreciated this institutional autonomy of the law. Christian Reus-Smit, for example, argues that there is an autonomous legal discourse that triggers demands of justification and thereby provides a certain form of resistance against the pursuit of self-interest. ${ }^{78}$ Arguing that prevalent explanations of legal obligation are deficient, ${ }^{79}$ he draws on an interstitial conception of politics that recognizes the co-constitution of power and morality. ${ }^{80}$ This view allows for an almost sacral dimension of legal obligation. Rather than through consent, obligation could be explained to a form of faith, 'the perceived legitimacy of an international legal system that upheld a divinely ordained social and political order'. ${ }^{81}$ From there, it is just a small step to acknowledging that the law constitutes an action system that cannot be adequately grasped through instrumentalist or functionalist analyses.

With respect to the interdisciplinary agenda, Reus-Smit holds that 'few of these bridge-building exercises start by critically reconsidering the foundational concepts on which these bridges will be reconstructed' ${ }^{82}$ Misunderstandings with respect to the fundamental tenets of legality are particularly problematic if the claim holds true that interdisciplinary scholarship increasingly moves from theoretical to practical perspectives. ${ }^{83}$ On a practical level, theoretical flaws remain uncorrected and ultimately lead to a distorted view of the legal process. The next section develops the argument of the institutional autonomy of the law, drawing on sociological writings on legal obligation. It holds that while there is no need to recur on mythical or sacral explanations for legal obligations, the autonomy of the law stands as the precondition for its critical discursive quality.

78 Reus-Smit, The Politics of International Law, in C. Reus-Smit, supra note 1, 14, at 37-38.

79 Reus-Smit, 'Politics and International Legal Obligation', 9 European Journal of International Relations (2003) 591, at 596 et seq.

${ }^{80}$ Reus-Smit, supra note 78, at 25.

${ }^{81}$ Reus-Smit, supra note 79, at 620.

82 Reus-Smit, 'Introduction', in Reus-Smit, supra note 1, 1, at 2.

${ }^{83}$ See, for example, the indications formulated in Irish et al., supra note 2, at 380-81. 


\section{The Critical Discursive Quality of Formalism}

This section illustrates the distinctive realm of legal argument as a matter of normative internalization from a participant's perspective that, at the same time, explains how law comes to be obligatory and binding. In order to make this point, it is important to note that thinking about legal obligation involves a doubling of perspectives. It is possible to look at law from an internal and external perspective. The external perspective aims at generalizations about the role of law in society, whereas the internal perspective tries to find a legal solution to a particular case.

This doubling of perspectives appears in many social theory treatments of law, for example, in the scholarship of Max Weber and Jürgen Habermas. Max Weber characterizes the juridical point of view: 'What is intrinsically valid as law? That is to say: What significance or, in other words, what normative meaning ought to be attributed in correct logic to a verbal pattern having the form of a legal proposition. But if we take [the sociological point of view], we ask: What actually happens in a group owing to the probability that persons engaged in social action [...] subjectively consider certain norms as valid and practically act according to them, in other words, orient their own conduct toward these norms? ${ }^{84} \mathrm{He}$ characterizes the internal point of view as pertaining to a particular kind of legal practice whereas the external point of view points to functions.

Jürgen Habermas picks up the distinction made by Weber and discusses their respective blind spots: 'The philosophical discourse of justice misses the institutional dimension, toward which the sociological discourse on law is directed from the outset. Without the view of law as an empirical action system, philosophical concepts remain empty. However, insofar as the sociology of law insists on an objectivating view from the outside, remaining insensitive to the symbolic dimension whose meaning is only internally accessible, sociological perception falls into the opposite danger of remaining blind'. ${ }^{85}$ Koskenniemi's criticism is reflected in these thoughts from Weber and Habermas. Both point to different perspectives to the law. Law is a distinctive discursive sphere only insofar one takes this internal perspective toward its normativity.

This internal perspective, ultimately, conveys a sense of legal obligation. Hart distinguished between the 'internal' and the 'external' point of view. ${ }^{86}$ According to him, the internal point of view is qualified by the attitude that

\footnotetext{
${ }^{84}$ M. Weber, Economy and Society, vol. 1 (1978), at 311.

85 J. Habermas, Between Facts and Norms (1996), at 66.

${ }^{86}$ Hart, supra note 46, at 89.
} 
one takes toward the law. Someone takes the internal point of view with a practical acceptance of the rules at stake. To accept a social rule means to suppose a certain behavior 'as a general standard to be followed by the group as a whole. ${ }^{87}$

Even though the external observer examines in detail the attitudes of the legal speakers and tries to incorporate the particularities of legal discourse, it can only inadequately take into account the internal (understood as 'internalized') point of view. ${ }^{88}$ Hart explains: 'For such an [external] observer, deviations by a member of the group from normal conduct will be a sign that hostile reaction is likely to follow, and nothing more. His view will be like the view of one who, having observed the working of a traffic signal in a busy street for some time, limits himself to saying that when the light turns red there is a high probability that the traffic will stop. He treats the light merely as a natural sign that people will behave in certain ways, as clouds are a sign that rain will come. In so doing he will miss out a whole dimension of the social life of those whom he is watching, since for them the red light is not merely a sign that others will stop: they look upon it as a signal for them to stop, and so a reason for stopping in conformity to rules which make stopping when the light is red a standard of behaviour and an obligation,. ${ }^{89}$

Ultimately, the acceptance and internalization of the normative content opens a discursive space since it allows for a specific form of critique. One criticizes actors (even oneself) for non-conformity using normative expressions and one even considers this criticism legitimate. ${ }^{90}$ Hart argues, ' $[\mathrm{w}]$ hat is necessary is that there should be a critical reflective attitude to certain patterns of behaviour as a common standard, and that this should display itself in criticism (including self-criticism), demands for conformity, and in acknowledgements that such criticism and demands are justified, all of which find their characteristic expression in the normative terminology of "ought", "must", and "should", "right" and "wrong". 91 The internal point of view offers the opportunity to contest claims in a particular kind of language. The specificity of this language gives rise to a practice of legality. ${ }^{92}$

${ }^{87}$ Ibid., at 56.

${ }^{88}$ For further discussion and explanations see Shapiro, 'What is the Internal Point of View?', 75 Fordham Law Review (2006) 1157.

${ }^{89}$ Hart, supra note 46, at 89-90.

90 Ibid., at 98 and 137-38.

91 Ibid., at 57.

92 See, for the ambiguities of this language, Roth-Isigkeit, 'The Grammar(s) of Global Law', 99 Critical Quarterly for Legislation and Law (2016) 175. 
In the context of the language of law, ideally the epistemic community of legal practice decides about the correctness of a claim. ${ }^{93}$ Whether legal claims are accepted depends on many things: consent, power, authority, or esthetic judgment. But acceptance in the community of law is not mechanical with a certain input-output prediction. ${ }^{94}$ It is open to hegemonic influence but not to determination. Koskenniemi holds: 'None of them [the approaches to law] can explain why this argument was held relevant, why that interpretation was chosen. The decision always comes about as political theorist Ernesto Laclau put it, as a kind of "regulated madness," never reducible to any structure outside it'. ${ }^{95}$ Carl Schmitt's anti-formalist claim that Caesar dominus et supra grammaticam, the emperor has authority over the grammar, is the opposite of this idea. ${ }^{96}$ The Schmittian conception that Koskenniemi discovers in interdisciplinary scholarship thus does not recognize legality as an autonomous discourse.

Formal law provides a space for the contestation of claims in legal language. This is an important function of the law, but this does not imply functionalism. There is a difference between functions (law as a critical tool) and functionalism (law as a tool to implement specific values). Law as a critical tool encourages a debate about the ends rather than presupposing them. This involves and encourages constructivist thinking about how legal concepts shape and change in practice. Yet, an important dimension of its critical function is dependent on the 'internal point of view' of legal practice, on arguments with an internalization of the legal form. This open practice as a practice of contestation requires that conflicts of values are carried to a shared language that moves discussions on the coordination of a complex society from the arbitrary confrontation of metaphysical claims to a specific context, the language of law. ${ }^{97}$

93 I. Johnstone, The Power of Deliberation: International Law, Politics, and Organizations (2011). Schachter, 'The Invisible College of International Lawyers', 72 Northwestern University Law Review (1977-1978) 217.

94 Fischer-Lescano and Liste, 'Völkerrechtspolitik', 12 Zeitschrift für Internationale Beziehungen (2005) 209, at 222.

95 Koskenniemi, 'The Epochs of International Law', 51 International and Comparative Law Quarterly (2002) 746.

96 C. Schmitt, 'Völkerrechtliche Formen des modernen Imperialismus', in C. Schmitt (ed.), Positionen und Begriffe im Kampf mit Weimar (2nd ed., 1988) 162. See also Fischer-Lescano and Liste, supra note 94, at 230.

97 This resonates with the classic account by Allott, 'Language, Method and the Nature of International Law', 45 British Yearbook of International Law (1971) 79, at 124-26. 


\section{Interdisciplinary Constructivism and Legal Obligation}

Having the Hartian description of the traffic signal in mind, we turn back to the three mischaracterizations of legal obligation that we have encountered in constructivist theories and confirm how they would describe the obligation to stop when the light is red. What has been described as the 'enchanted' view would suggest that one is obligated to stop at a traffic signal because more traffic regulation is always the better policy option. Sociological instrumentalism would argue that traffic regulation fulfills important functions for order, it determines who is allowed to drive on the road and avoids accidents. In short, it makes traffic more secure. Normative instrumentalism would determine that it is a good thing that traffic is regulated because this avoids conflicts and gives weaker actors, like pedestrians, the possibility to participate with same rights in traffic. All this seems to make sense until we consider the obligation to stop at a traffic light at a lonely crossing in the countryside in the middle of the night, where these generalized functions of traffic lights cease to be necessary. Of course, we do have an obligation to stop at the traffic signal independent of whether this seems to make sense to us. The source of the obligation does not equal the reasons for traffic signals in general. If we go through, we are subject to criticism simply because it is the law to stop. The source of this criticism, however, is entirely formal. It has nothing to do with the reasons for or against traffic signals.

Functional approaches, in contrast, impede on the critical function of the law because they have an externally dependent concept of legal validity. The central difference to formalism is the claim that whether a norm belongs to the body of law can only be decided after an examination of the norm properties, like the realization of Fuller's criteria or 'human dignity'. The consequence is a fluid concept of legal validity that leads to the loss of the internal critical space. Whenever a state (or an individual) is criticized for non-obedience of the law, a fluid concept of validity opens an easy defense that blurs its necessity for justification.

When a state questions the validity of a norm on the basis of external criteria, the argument that follows has nothing to do with the concrete case anymore. Since validity is to be examined before the facts, one needs to argue why the law, on an abstract level, should be valid. Absent formal criteria this will lead you to an argument about other criteria for validity: effectiveness or morality. The absence of formal criteria of validity (soft law, regulation, governance) is precisely the interdisciplinary agenda. The distinctiveness of legal argument, the discussion of a factual situation in relation to a counterfactual normative standard gets lost.

This is why the practice of law requires resort to a concept of autonomy. It is not that one could make the argument of subjection against every other 
interdisciplinary project as Dunoff suspects. ${ }^{98}$ Rather, it is a specific feature that arises as a consequence of the formality of legal rules. Probably the finest nuance of the problem can be found in a question by Dunoff: 'And why, exactly', he asks, 'does Koskenniemi view the turn to International Relations as so problematic - particularly given that Koskenniemi sometimes criticizes International Relations approaches as being too Kantian, and other times criticizes IR theory for not being Kantian enough?'99 Koskenniemi as I understand him means two different Kantian themes: The lack of the Kantian mind-set points to the distinction between law and morality, a strict separation of the two spheres. When the form of law corrodes in the anti-formalism of IL/IR approaches, it is replaced by Kantian morality based on universalized individual reason. Kantian morality suffers from the problem that a universalization can only be justified on shared rather than individual understandings, the classical Habermasian requirement of discourse ethics. IL/IR approaches are not Kantian enough when it comes to form whereas they are too Kantian when it comes to universal reason.

\section{Reflexive Formalism as a Multidisciplinary Project}

Ultimately, this plea for a formalist method aims to protect the critical discursive space of the law. It thus underscores Koskenniemi's warning from an uncritical enchantment of functional approaches. At the same time, in order to push forward a constructive agenda, the question remains what role cooperation between both disciplines can and should play. I believe, the first step to such an approximation of meaningful cooperation is intellectual modesty. ${ }^{100}$ One of the foundational flaws of the IL/IR project was to understand its research as an exercise in legal method. ${ }^{101}$ At the same time, it is important to acknowledge that lawyers might need intellectual support from neighboring disciplines. This ultimate section thus aims to sketch the way social science methodology can meaningfully contribute to practices of legality.

The key to this is the recognition of different dimensions in legal method. While the argument insisted on the distinction between internal and

98 Dunoff, supra note 3, at 331.

${ }^{99}$ Dunoff, supra note 3, at 310.

${ }^{100}$ Elsewhere, I have advocated this modesty in the theory of global law. See D. Roth-Isigkeit, The Plurality Trilemma - A Geometry of Global Legal Thought (forthcoming, 2018).

${ }^{101}$ For this view, see Ratner and Slaughter, supra note 1. See also Koskenniemi, 'Symposium on Method in International Law: Letter to the Editors of the Symposium', 93 American Journal of International Law (1999) 351. 
external perspective, the problem of interdisciplinarity is located in the relationship between both perspectives on the law. Legally, a whale can be defined as a fish in certain circumstances, whereas biologically it stays a marine mammal. The lawyer has to take the internal standpoint to treat the animal, for example, in the context of harbor regulations as a fish, whereas at the same time she knows (even though she would not have to) that it is not a fish. The autonomy of law - in particular circumstances - takes an 'external point of view' toward reality. From an internal perspective law has to be autonomous whereas from an external perspective it can and should be criticized.

Since taking the internal point of view does not presuppose moral agreement with the legal norm, ${ }^{102}$ there is no contradiction between defending the methodological basis of legal reasoning and a normative critique of legal norms. Formalism is a mode in which law can meaningful order a society but at the same time it must be possible to criticize the very conditions under which this mode leads to iniquities. Critical approaches thereby complement formalist approaches to international law. Whereas the former exercise their critical function through the law, the latter provide criticism of that law.

The support of social science methods should thus concentrate on the external perspective on legality. Here, it can give advice as to what potentially works, where legal change could be appropriate and how legal regimes should be designed. This external support, abstaining from claims on practices of legal argumentation, will certainly improve the understanding of international law as an important part of international relations. In the best case, social scientists will even become interested in the internal dimension of these practices. Good scholarship in international theory should be able to simultaneously appreciate the internal and external perspectives on the law. This is also a challenge for lawyers. In legal method, this doubling in perspectives provides for a reflexive formalism. In an adequate description, it turns legal argumentation into an 'as if' mode. ${ }^{103}$ Legal discourse can only function if it can - in awareness of the political nature of the law - ignore the politics for the purpose of argumentation. ${ }^{104}$

This reflexive method also speaks from Kratochwil's and Onuf's work. ${ }^{105}$ Both seem to recognize the distant relationship between both

102 Hart, supra note 46, at 257.

103 See Knop et al., 'From Multiculturalism to Technique - Feminism, Culture and the Conflicts Of Law Style', 64 Stanford Law Review (2012) 589, at $642 \mathrm{f}$.

104 Ibid., at 647.

105 I am grateful to one anonymous reviewer for pressing me on this. 
methods. In one of his younger essays, Onuf offers an account that presents both disciplines as distinct crafts: 'While scientists use evidence to substantiate claims about what happens in the world, lawyers bring evidence to bear on their claims as to which law and what practices should and do matter to their clients, judges, the world'. ${ }^{106}$ Kratochwil equally acknowledges this view, offering in his recent book a rather sociological perspective on interdisciplinary inquiries. ${ }^{107} \mathrm{He}$ argues that if we want to cast our net wider, we must face the problem that all of our knowledge is based on disciplinary understandings, even if we thereby do not have to accept the proposition that there is only one method that we can use'. ${ }^{108}$ Abstaining from bold claims about what the law is and what lawyers do will support tendencies within International Relations for a meaningful and qualitative engagement with the law. ${ }^{109}$

In terminology, this distinction points to a multi- rather than an interdisciplinary enterprise. It grants the law its institutional autonomy while equally embodying important constructions and critiques from social science methodology. The reflexive formalist understanding of law allows it to capture the obligating nature of the law independent of the normative content of particular legal rules. This doubling in perspectives resonates well with the Hartian characterization of the internal and the external point of view. A multidisciplinary inquiry is capable to simultaneously acknowledge different perspectives on a given subject, without necessarily needing to unite them in a form of interdisciplinary method.

\section{Acknowledgments}

The author would like to thank Stefan Kadelbach, Thomas Kleinlein, Anna Katharina Mangold, Tanja Aalberts, Evan J. Criddle, and Steven R. Ratner for helpful comments and suggestions on previous versions of this article.

106 N. Onuf, 'Practicing theory', in Onuf, supra note 45, 429, at 438.

${ }^{107}$ Kratochwil, supra note 49, at 26-49.

108 Ibid., at 28.

109 See, for a positive example, the perspectives in K. Alter, The New Terrain of International Law: Courts, Politics, Rights (2014), at 4, who recognizes the linguistic autonomy of the law and Reus-Smit, supra note 78. An introductory text mediating between the different theoretical positions contained in this article is B. Cali (ed.), International Law for International Relations (2009). 